\title{
SCREENING Candida albicans PENYEBAB KANDIDIASIS ORAL DAN EDUKASI ORAL HYGIENE PADA LANSIA DI PANTI SOSIAL TRESNA WERDHA WANA SERAYA BALI
}

\author{
Ni Wayan Desi Bintari ${ }^{1 *}$, Ika Setyapurwanti², Ni Luh Putu Devhy², \\ Anak Agung Oka Widana ${ }^{2}$, Diah Prihatiningsih ${ }^{3}$ \\ ${ }^{1}$ Prodi D3 Teknologi Laboratorium Medis STIKes Wira Medika Bali \\ ${ }^{2}$ Prodi D3 Rekam Medis dan Informasi Kesehatan STIKes Wira Medika Bali \\ ${ }^{3}$ Program Studi S1 Keperawatan STIKes Wira Medika Bali \\ "desibintari@gmail.com
}

\begin{abstract}
ABSTRAK
Sebagian besar kelompok lansia di Indonesia diketahui memiliki pengetahuan dan kesadaran yang kurang terhadap infeksi yang mungkin terjadi pada rongga mulut. Padahal pada fase lansia seseorang mengalami penurunan fungsi imun tubuh yang mendorong infeksi oppurtunistik salah satunya kandidiasis oral. Penyuluhan terkait oral hygiene sangat perlu dilakukan untuk mendorong terjadinya perubahan perilaku dari aspek pengetahuan, sikap dan tindakan lansia dalam menjaga kesehatan rongga mulut. Pengabdian masyarakat ini dilakukan untuk melakukan screening Candida albicans penyebab kandidiasis oral dan melakukan edukasi melalui pendekatan personal approach terkait oral hygiene pada lansia. Kegiatan pengabdian masyarakat dilakukan di Panti Sosial Tresna Werdha Wana Seraya Bali. Jumlah lansia yang mengikuti kegiatan sebanyak 33 orang dimana sebanyak 12 orang bersedia diambil sampel swab mukosa mulutnya untuk dilakukan isolasi dan identifikasi Candida albicans. Hasil screening terhadap Candida albicans didapatkan 2 hasil kultur positif sehingga diduga terdapat lansia yang terindikasi kandidiasis oral dan perlu dilakukan pemeriksaan lebih lanjut. Edukasi terkait oral hygiene yang diberikan kepada lansia meliputi penyuluhan kebersihan gigi dan mulut, menyikat gigi, pemeliharaan gigi palsu, pengaturan diet untuk menjaga kesehatan rongga mulut dan infeksi pada rongga mulut. Selama pelaksanaan penyuluhan lansia sangat antusias mengikuti kegiatan dan diharapkan lansia bisa terus melaksanakan oral hygiene sebagai kebiasaan sehari-hari.
\end{abstract}

Kata Kunci : Oral hygiene, Candida albicans, Lansia

\section{ABSTRACT}

Most of the elderly groups in Indonesia are known to have less knowledge and awareness of oral infections, wherease aging phase in well known will affects immune function which encourages oppurtunistic infections, such as oral candidiasis. Counseling related to oral hygiene is very necessary to encourage behavioral changes in the aspects of knowledge, attitudes and actions of the 
elderly in maintaining oral health. This community service is carried out to screening and identify Candida albicans the causative agent of oral candidiasis and conduct education through a personal approach related to oral hygiene in elderly. Community service activities were carried out at Nursing Home (Panti Sosial Trena Werdha) Wana Seraya Bali. The number of elderly who participated in this activity was 33 people in which 12 people were willing to be a respondent for oral swab for isolation and identification of Candida albicans. The results of microbiological examination showed that 2 culture were positive Candida albicans. From the result we suspected that 2 respondent indicated oral candidiasis and needed further examination. Education related to oral hygiene provided to the elderly includes counseling on oral and dental hygiene, brushing teeth, dentures care and healthy diet to maintenance oral health. Participants were very enthusiastic during program and hopefully could continue to carry out oral hygiene as a daily habit.

Key words : Oral hygiene, Candida albicans, Elderly 


\section{PENDAHULUAN}

Kandidiasis oral atau oral trush merupakan salah satu infeksi pada rongga mulut yang disebabkan oleh infeksi jamur dari genus Candida khususnya spesies Candida albicans. Kandidiasis yang tidak segera dirawat dapat berkembang menjadi kandidiasis keukoplakia yang bersifat pra ganas dan kemudian menyebabkan karsinoma sel skuamosa[1]. Infeksi kandidiasis oral dapat terjadi pada berbagai kalangan usia. Namun beberapa tahun terakhir diketahui kandidiasis oral mengalami peningkatan angka kejadian infeksi pada kelompok lanjut usia atau lansia[2,3].

Peningkatan angka kejadian kandidiasis oral pada lansia menurut Silva[4] dapat dipengaruhi oleh berbagai faktor. Beberapa studi telah melakukan evaluasi mengenai hubungan peningkatan kandidiasis oral dengan penggunaan gigi palsu (denture)[5], jumlah dan $\mathrm{pH}$ saliva pada lansia[6], serta penggunaan antibiotik dan diet[7]. Sato et al.[8] juga menyatakan kolonisasi $C$. albicans dan non-albicans pada rongga mulut sangat dipengaruhi oleh kondisi higiene atau kebersihan seseorang yang meliputi gaya hidup dan kebersihan lingkungan. Lebih jauh Yano et al.[9] menyatakan pada kelompok lansia terjadi penurunan kondisi tubuh yang disebabkan oleh penurunan fungsi imun tubuh

Sebagian besar kelompok lansia di Indonesia diketahui memiliki pengetahuan dan kesadaran yang kurang terhadap infeksi yang mungkin terjadi pada rongga mulut. Sehingga sangat diperlukan adanya pendekatan oleh tenaga kesehatan maupun dokter gigi untuk mengatasi permasalahan rongga mulut pada lansia[10]. Abikusno[11] menyatakan salah satu upaya dalam mencegah terjadinya infeksi rongga mulut adalah melalui edukasi atau penyuluhan secara berkala. Melalui penyuluhan diharapkan dapat mendorong terjadinya perubahan perilaku dari aspek pengetahuan, sikap dan tindakan ke arah perilaku sehat.

Penyuluhan terkait oral hygiene pada lansia menurut Irawati et al.[12] sangat penting dilakukan mengingat lansia memiliki perubahan integritas gigi dan mukosa serta ketidakmampuan lansia dalam melakukan 
perawatan mulut. Oral hygiene yang buruk dapat menyebabkan berbagai permasalahan bagi lansia. Adanya luka terbuka atau sakit gigi pada lansia dapat menimbulkan infeksi mulut yang menyebabkan masalah pernafasan pada lansia. Oral hygiene yang buruk juga meningkatkan kolonisasi Candida albicans pada rongga mulut yang dapat berkembang menjadi kandidiasis oral.

Hasil analisa situasi yang dilakukan di Panti Sosial Tresna Werdha (PSTW) Wana Seraya Bali menunjukkan lansia di panti tersebut kurang memahami bahaya infeksi pada rongga mulut khususnya terkait kandidiasis oral, sehingga sangat penting dilakukan screening awal sebagai tindakan pencegahan sebelum terjadi infeksi kronis dan sistemik. Selain itu kepatuhan lansia dalam menjaga kesehatan rongga mulutnya juga perlu dievaluasi. Edukasi terkait pemeliharaan kesehatan gigi dan mulut melalui oral hygiene sangat perlu dilakukan guna meningkatkan kesadaran lansia terkait pentingnya menjaga kesehatan rongga mulut. Panti Sosial Tresna Wredha (PSTW) Wana Seraya yang merupakan salah satu panti sosial di Bali yang menampung lansia dengan usia 60 tahun ke atas. Hingga tahun 2019, jumlah lansia yang ditampung oleh PSTW Wana Seraya berjumlah 49 orang yang terdiri atas 10 lansia laki-laki dan 39 lansia perempuan. Kondisi panti dan lansia di PSTW ini cukup baik dan kondusif karena lansia dibekali dengan kegiatan berkarya yang nantinya dijadikan sumber bekal tambahan bagi lansia.

\section{METODE PELAKSANAAN}

Kegiatan pengabdian masyarakat dilaksanakan di Panti Sosial Tresna Werdha Wana Seraya (PSTW) yang beralamat di Jalan Bakung I Kesiman Kertalangu Denpasar Timur. Kegiatan yang dilakukan meliputi pemeriksaan mikrobiologi Candida albicans penyebab kandidiasis oral dan edukasi oral hygiene melalui penyuluhan terkait kesehatan rongga mulut dan kandidiasis oral kepada lansia. 


\section{Pemeriksaan Mikrobiologi Candida albicans}

Pemeriksaan mikrobiologi terhadap Candida albicans dilakukan dengan melakukan isolasi ragi pada sampel swab mukosa mulut lansia. Teknik pengambilan sampel dilakukan dengan purposive sampling yang memenuhi kriteria inklusi dan eksklusi. Kriteria inklusi meliputi 1) responden yang bersedia diambil sampelnya; 2) responden dengan usia $\geq$ 60 tahun; 3) responden tidak sedang menjalani perawatan terkait infeksi gigi dan mulut. Sementara itu kriteria eksklusi yang digunakan adalah responden yang tidak mampu berkomunikasi dengan baik dan memiliki gangguan kesehatan psikis dan mental. Analisa mikrobiologi sampel dilakukan di Laboratorium STIKes Wira Medika Bali. Sampel dikultivasi pada media Sabourauds Dextrose Agar (SDA) selama 24-48 jam pada suhu $38^{\circ} \mathrm{C}$. Koloni yang tumbuh dilakukan pengecatan untuk melihat struktur mikroskopis jamur dengan menggunakan lactofenol cotton blue. Identifikasi dilakukan secara makroskopis koloni dan mikroskopis dengan mengamati struktur pseudohifa dan blastospora.

\section{Penyuluhan Oral Hygiene}

Kegiatan penyuluhan dilakukan berdasarkan pendekatan perorangan atau personal approach. Pendekatan perorangan ini dipilih karena sasaran dalam penyuluhan dapat secara langsung memecahkan masalahnya dengan bimbingan khusus dari penyuluh. Selain itu melalui personal approach penyuluh lebih mudah berkomunikasi dengan lansia sehingga semua informasi yang diberikan dapat dimengerti dengan baik oleh sasaran penyuluhan. Materi penyuluhan yang disampaikan pada kegiatan ini meliputi kesehatan gigi dan mulut, bahaya kandidiasis oral dan oral hygiene yang meliputi menyikat gigi dan dental flossing serta kontrol diet untuk menjaga kesehatan gigi dan mulut. Sebelum kegiatan penyuluhan dilakukan lansia dituntun untuk mengisi kuisioner pre-test singkat sebagai gambaran awal tingkat pengetahuan terhadap infeksi rongga mulut dan kepatuhan lansia terhadap oral hygiene. Setelah 
kegiatan penyuluhan berlangsung, lansia juga dipandu untuk mengisi kuisioner post-test yang bertujuan untuk mengevaluasi hasil penyuluhan yang dilakukan.

\section{HASIL DAN PEMBAHASAN}

\section{Pemeriksaan Mikrobiologi Candida albicans}

Pemeriksaan Candida albicans dilakukan dengan melakukan pemeriksaan laboratorium terhadap swab mukosa mulut lansia. Berdasarkan kriteria pemilihan sampel adapun responden yang memenuhi kriteria pengambilan sampel sebanyak 12 responden. Responden terdiri atas 6 responden perempuan dan 6 responden laki-laki dengan usia ratarata diatas 55 tahun. Hasil pemeriksaan kultur jamur terhadap Candida albicans didapatkan dari 12 sampel yang dilakukan kultivasi terdapat 2 sampel $(16,67 \%)$ yang positif pertumbuhan Candida albicans sedangkan sisanya sebanyak $83,33 \%$ menunjukkan hasil negatif. Identifikasi terhadap C. albicans dilakukan dengan mengamati pola pertumbuhan koloninya yang khas pada media SDA setelah 3-5 hari masa inkubasi serta karakteristik mikroskopis yang dimiliki oleh jamur tersebut melalui pengamatan di bawah mikroskop (Gambar 1.).

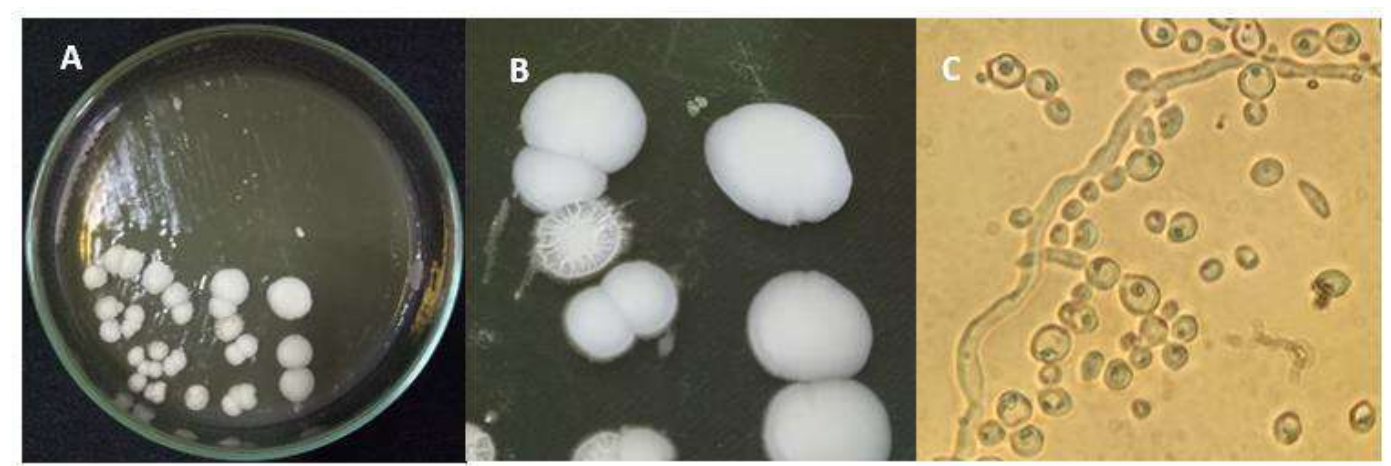

Gambar 1. Jamur Candida albicans. Koloni $C$. albicans pada media SDA dengan usia kultur 5 hari (a), koloni berwarna putih, berbentuk bulat halus dengan tepi rata (b), gambar mikroskopik jamur tampak adanya pseudohifa dan blastospora

(c) 
Candida albicans pada media SDA memiliki koloni yang khas berwarna putih. Koloni berbentuk bulat dengan permukaan sedikit cembung, halus, licin dan tampak seperti pasta (Gambar 1 (a,b)). Diameter koloni pada usia 3 hari $\pm 4 \mathrm{~mm}$ dan pada usia 5 hari $\pm 7 \mathrm{~mm}$. Pada usia 3 hari atau lebih pertumbuhan koloni pada media sangat khas berbau asam seperti aroma tape. Secara mikroskospis dengan pewarnaan lactofenol cotton blue dan lugol dapat diamati struktur seperti ragi atau yeast like. Sel ragi atau dikenal dengan blastospora berukuran besar, berbentuk bulat atau seperti botol. Sel ini dapat berkembang menjadi klamidospora yang berdinding tebal. Selain itu pengamatan mikroskopis juga menunjukkan terdapat hifa semu atau pseudohifa (Gambar 1 (c)).

Candida albicans merupakan mikroorganisme yang hidup secara komensal di dalam rongga mulut, saluran pencernaan dan alat genital. Infeksi terjadi apabila terdapat ketidakseimbangan antara mikroorganisme penyebab ( $C$. albicans) dan daya tahun tubuh hospes baik karena virulensi dan jumlah jamur yang meningkat ataupun karena daya tahan tubuh hospes yang menurun[13]. Jumlah normal $C$. albicans dalam rongga mulut kurang dari $200 \mathrm{sel} / \mathrm{ml}$ saliva. Keadaan ini dapat berubah menjadi patogen pada pasien yang menderita berbagai maam kelainan sistemik yang melemahkan (leukimia, limfoma dan diabetes)[14].

Infeksi oleh $C$. albicans juga sangat dipengaruhi oleh faktor lokal. Beberapa faktor lokal tersebut seperti penggunaan gigi tiruan, xerostomia, dan kebiasaan merokok. Penggunaan gigi tiruan dapat memberikan lingkungan yang kondusif bagi pertumbuhan jamur kandida yaitu lingkungan dengan $\mathrm{pH}$ yang rendah, sedikit oksigen, dan keadaan anaerob. Faktor lokal seperti xerostomia juga dapat menimbulkan kandidiasis oral. Xerostomia merupakan suatu kondisi dimana mulut terasa kering. Hal ini dapat disebabkan oleh berkurangnya produksi saliva, penggunaan obat-obatan (obat antihipertensi), terapi radiasi dan kemoterapi[15]. 


\section{Penyuluhan Oral Hygiene dan Kandidiasis Oral}

Berdasarkan hasil kusioner pre-test terhadap tingkat pengetahuan dan ketaatan lansia terhadap kesehatan rongga mulut diketahui sebesar $84,84 \%$ lansia kurang taat dalam melakukan oral hygiene khususnya menggosok gigi secara teratur. Sebanyak 93,93\% lansia menyatakan tidak mengunjungi dokter gigi untuk memeriksakan keluhan infeksi pada rongga mulut dan gigi yang dialami. Data kuisioner juga menunjukkan bahwa sebanyak $78,78 \%$ lansia memiliki gigi yang berlubang dan mengganggu aktivitasnya dalam mengunyah makanan ataupun mengkonsumsi makanan yang keras. Ketika pengumpulan data dilakukan juga diketahui sebanyak 33,33\% lansia mengeluhkan sariawan/ luka pada gusi. Berdasarkan hasil wawancara yang dilakukan sebagian besar lansia mengkonsumsi obat bebas (logo biru) untuk meredakan rasa nyeri yang dialami saat sakit gigi ataupun sariawan. Beberapa responden juga menyatakan menggunakan obat tradional untuk menghilangkan sakit gigi atau sariawan yang dialami tanpa melakukan pemeriksaan lanjutan ke dokter gigi. Data kuisioner juga menunjukkan keseluruhan lansia (100\% sasaran) belum mengetahui terkait infeksi kandidiasis oral serta bahaya dan faktor resiko dari infeksi tersebut.

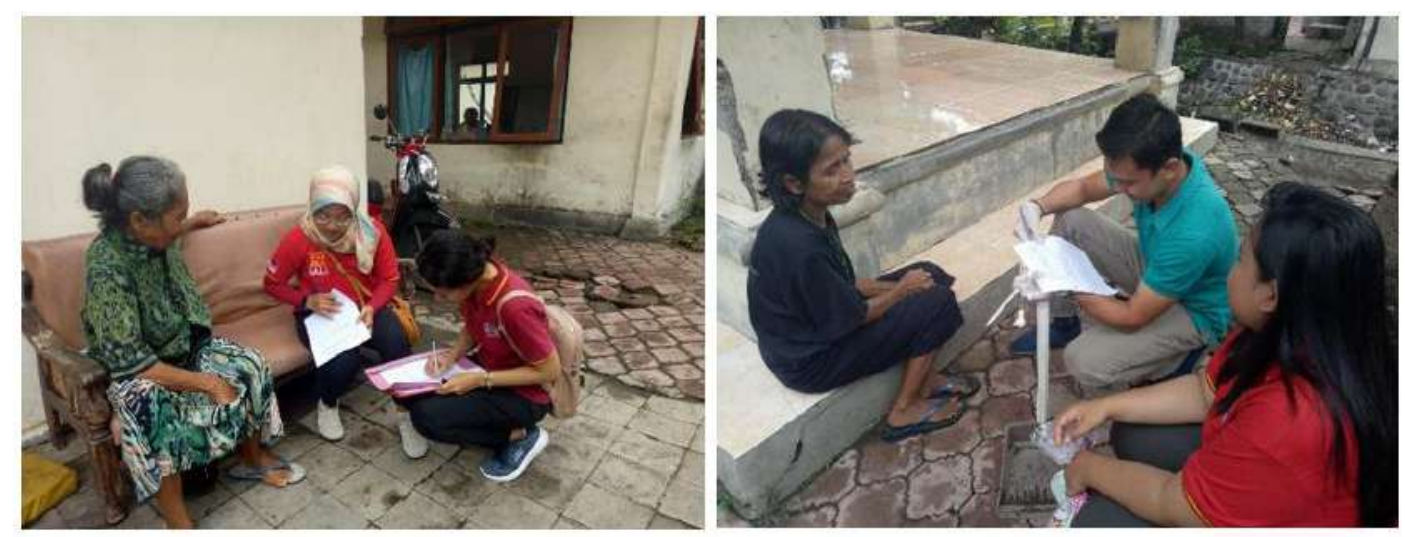

Gambar 2. Proses pendataan dan pendampingan pengisian kusioner 
Penyuluhan yang dilakukan melalui personal approach ini diikuti dengan antusias oleh semua lansia. Materi penyuluhan yang diberikan secara umum lebih difokuskan kepada tindakan atau langkah-langkah oral hygiene yang dapat diterapkan lansia sehari-hari. Lansia diingatkan untuk selalu menyikat gigi dan kumur-kumur secara teratur meskipun sudah ompong. Bagi lansia yang memiliki gigi cukup lengkap dianjurkan menyikat giginya sendiri secara perlahan sebanyak 2 kali sehari pada pagi dan malam sebelum tidur, termasuk bagian gusi. Apabila ada gigi berlubang dan ada endapan warna kuning sampai cokelat lansia dianjurkan untuk segera mengunjungi puskesmas. Bagi lansia yang tidak mempunyai gigi sema sekali juga dianjurkan setiap selesai makan harus menyikat secara lembut bagian gusi dan lidah dengan menggunakan sikat gigi yang lembut atau kain lembut untuk membersihkan sisa makanan yang melekat. Lansia yang tidak memiliki gigi juga disarankan berkumur setiap sehabis makan untuk membersihkan sisa makanan. Lansia juga dianjurkan waspada apabila merasakan nyeri, luka dan berdarah dalam rongga mulut selama lebih dari 2 minggu atau lebih dan segera meminta nasehat dari dokter gigi terdekat.

Pada kegiatan penyuluhan ini lansia secara bertahap diberikan informasi terkait kandidiasis oral yang meliputi gejala infeksi serta faktorfaktor yang mempengaruhi infeksi. Lansia diberikan penekanan terhadap faktor-faktor resiko yang meningkatan potensi perkembangan jamur kandida di dalam mulut seperti penyakit diabetes, penggunaan gigi tiruan, kebiasaan merokok dan xerostomia. Sebagai upaya mencegah infeksi jamur di dalam mulut tersebut lansia diberikan pengetahuan terkait cara merawat kebersihan gigi palsu yang baik serta lansia dibekali pengetahuan terkait diet sehat untuk mencegah terjadinya diabetes dan xerostomia yang dapat berpengaruh terhadap kesehatan rongga mulut dan meningkatkan resiko infeksi kandidiasis oral.

Berdasarkan kuisioner post test yang dilakukan 3 hari setelah penyuluhan dilakukan diketahui lansia sudah mulai taat dan 
memperhatikan kesehatan rongga mulutnya. Hasil post-test menunjukkan diketahui sebanyak $75,75 \%$ lansia telah paham bahwa menyikat gigi yang baik dilakukan sebanyak 2 kali sehari yaitu pagi dan malam hari sebelum tidur. Selain itu kegiatan menyikat gigi juga telah dilakukan dengan menggunakan pasta gigi berflouride. Meskipun demikian berdasarkan wawancara yang dilakukan saat pengisian kuisioner post-test lansia di PSTW Wana Seraya memang belum ada yang melakukan pemeriksaan terhadap gigi dan mulutnya ke puskesmas.

Meskipun penyuluhan terkait oral hygiene ini masih sangat sederhana tetapi diharapkan mampu membantu lansia di PSTW Wana Seraya terkait pendidikan oral hygiene dalam menunjang kesehatannya. Menurut Petersen[16] terdapat 4 strategi yang dapat dilakukan penyuluh terkait edukasi oral hygiene diantaranya (1) mengurangi penyakit mulut terutama pada lansia yang tinggal di pinggiran dan tergolong miskin; (2) mempromosikan gaya hidup bersih dan sehat untuk mengurangi faktor resiko infeksi gigi dan mulut; (3) merespon lansia untuk meningkatkan kesehatan mulutnya dan (4) mempromosikan perawatan kesehatan mulut secara efektif. Melalui edukasi yang diberikan selama penyuluhan diharapkan mampu meningkatkan pengetahuan dan kebiasaan lansia dalam melakukan oral hygiene sehari-hari.

\section{SIMPULAN DAN SARAN}

\section{Simpulan}

Hasil screening secara mikrobiologis terhadap Candida albicans pada lansia di PSTW Wana Seraya didapatkan 2 hasil kultur positif sehingga diduga terdapat lansia yang terindikasi kandidiasis oral dan perlu dilakukan pemeriksaan lebih lanjut. Terkait hasil tersebut lansia telah dibekali dengan edukasi terkait oral hygiene melalui penyuluhan yang ditanggapi dengan antusias oleh semua lansia. Penyuluhan oral hygiene dengan pendekatan personal approach dapat meningkatkan pengetahuan 
lansia terkait pentingnya oral hygiene yang nantinya diharapkan dapat membantu menurunkan permasalahan kesehatan mulut pada lansia.

\section{Saran}

Kegiatan pengabdian masyarakat di PSTW Wana Seraya terkait oral hygiene disarankan untuk diselenggarakan secara periodik. Pengabdian lanjutan oleh tenaga medis terkait pemeriksaan kesehatan gigi dan mulut sangat baik untuk dilakukan selanjutnya untuk memberikan bantuan bagi lansia yang memiliki masalah dengan gigi dan mulut. Selain itu disarankan tenaga medis terkait juga dapat melakukan pemeriksaan lanjutan terkait infeksi kandidiasis oral untuk membantu penegakan diagnosis dan pengobatan yang sesuai.

\section{DAFTAR PUSTAKA}

1. Hakim, L., R. Ramadhian. 2015. Kandidiasis oral. Majority. 4(8): 5357.

(http://juke.kedokteran.unila.ac.id/index.php/majority/article/download/ $1407 / 1251)$

2. Sakaguchi, H. 2017. Treatment and prevention of oral candidiasis in elderly patients. Med. Mycol J. 58(2): 43-49. (https://www.ncbi.nlm.nih.gov/pubmed/28566666)

3. Sari, M. 2014. Gambaran Kolonisasi Candida Oral Pada Lansia di UPTD Rumoh Seujahtra Geunaseh Sayang Ulee Kareng Banda Aceh. (Skripsi). Aceh. Universitas Syiah Kuala.

4. Silva, H.P.R., B. Koppe., M.C. Brew., G.S. Soria., C.S. Bavaresco. 2017. Approach to the most prevalent oral disorders among the elderly: an integrative focusing on primary health care. Rev. Bras. Gerontol. 20(3): 430-440. (http://www.scielo.br/scielo.php? script=sci_arttext\&pid=S1809-98232017000300430)

5. Gleiznys, A., E. Zdanaviciene., J. Zilinskas. 2015. Candida albicans Importance to Denture Wearers. A Literature Review. Stomatologija, 
Baltic and Maxillofacial Journal. 17: 54-66.

(https://www.ncbi.nlm.nih.gov/pubmed/26879270)

6. Gani, B.A., C. Soraya., Sunnati., A.I. Nasution., N. Zikri., R. Rahadianur. 2013. Perubahan pH Saliva Buatan Setelah Diinteraksikan Dengan Candida albicans, Streptococcus mutans, dan Aggregatibacter actinomycetemcomitans. Cakradonya Dent J. 5(2): 542-618. (http://jurnal.unsyiah.ac.id/CDJ/article/view/10380)

7. Kraff-Bodi, E., M.R. Jorgensen., M.K. Keller., C. Kragelund., S. Twetman. 2015. Effect of probiotic bacteria on oral candida in frail elderly. J. Dent Res. 94(9): 181-186. (https://www.ncbi.nlm.nih.gov/pubmed/26202995)

8. Sato, T., M. Kishi., M. Suda., K. Sakata., H. Shimoda., H. Miura., A. Ogawa., S. Kobayashi. 2017. Prevalence of Candida albicans and non-albicans on the tongue dorsa of elderly people living in a postdisaster area: a cross-sectional survey. BMC Oral Health. 17(51): 1-5. (https://www.ncbi.nlm.nih.gov/pmc/articles/PMC5288978/)

9. Yano, A., A. Abe., F. Aizawa., H. Yamada., K. Minami., M. Matzui., M.Kishi. 2013. The effect of eating sea cucumber jelly on Candida load in the oral cavity of elderly individuals in a nursing home. Mar Drugs. 11:

4993-5007.

(https://www.ncbi.nlm.nih.gov/pmc/articles/PMC3877898/)

10. Ermawati, T., D. Sandrasari., Yuliana. 2013. Upaya peningkatan kesehatan gigi dan mulut pada lansia. Lembaga Pengabdian Kepada Masyarakat, Universitas Jember. (https://repository.unej.ac.id/bitstream/handle/123456789/65035/drg.\% 20TANTIN\%20ERMAWATI\%20M.Kes._artikel\%20XX.pdf?sequence= 1\&isAllowed $=\mathrm{y}$ )

11. Abikusno, N. 2013. Kelanjutusiaan Sehat Menuju Masyarakat Sehat Untuk Segala Usia. Buletin Jendela Data dan Informasi Kesehatan. ISSN 2088-270X. 
12. Irawati., A. Sudaryanto., Irdawati. 2012. Pengaruh Pendidikan Kesehatan Terhadap Pengetahuan Oral Hygiene Pada Lanjut Usia di Wilayah Kerja Puskesmas Karangmalang Kabupaten Sragen. Fakultas IImu Kesehatan. Universitas Muhammadiyah Surakarta. (http://eprints.ums.ac.id/21974/)

13. Monica, B., M.Gupta. 2013. Oral Candidiasis and AIDS. IOSR-JDMS. 11: 29-32. (https://www.iosrjournals.org/iosr-jdms/papers/Vol11issue4/G01142932.pdf?id=8206)

14. Brooks, G.F., J.S. Butel., L.N. Ornston. 2010. Jawetz, Melnick \& Adelberg Mikrobiologi Kedokteran. Jakarta. Penerbit Buku Kedokteran EGC.

15. Fourie, J., R.A.G. Khammissa., R. Ballyram., N.H. Wood., J. Lemmer., L. Feller. 2016. Oral candidosis: an update on diagnosis, aetiopathogenesis and management. SDAJ. 71(7): 314-318. (http://www.scielo.org.za/scielo.php?script=sci_arttext\&pid=S001185162016000700007)

16. Petersen, L. 2005. Stop and Think Learning (Bagaimana Memotivasi Belajar). Jakarta: Gramedia. 